\title{
Enhancing Students' Higher-Order Thinking Skills Through Guided and Free Inquiry-Based Learning
}

\author{
Zulfiani, Regiani Yunistika, Nengsih Juanengsih \\ Syarif Hidayatullah State Islamic University Jakarta, Jl. Ir. H. Djuanda 95, Ciputat, Indonesia \\ Corresponding e-mail: zulfiani@uinjkt.ac.id
}

\begin{abstract}
The study aims to determine the effectiveness of guided inquiry and free inquiry to improve students' higher-order thinking skills (HOTS). The quasi-experiments was conducted using non-equivalent pretest post-test control group design. Simple random sampling was used as the sampling technique with 64 students. The essay instrument was designed to measure students' HOT on three divisions of Fungi, namely, Zygomycota, Ascomycota, and Basidiomycota. The results show a significant increase of higher-order thinking skills towards student ability categories from both guided inquiry and free inquiry learning model. However, the two models of inquiry do not give a significant difference of students' HOTS and gender.
\end{abstract}

Keywords: $\quad$ higher-order thinking skills, guided inquiry, free inquiry

\section{INTRODUCTION}

Programme for International Student Assessment (PISA), implemented by OECD in 2009 has performed several research studies to discover the ability to read literacy, mathematics and science of 15 years old students in 65 countries. The results indicates that the ability of Indonesian students' mathematics literacy was ranked 55th with score 371 out of 65 countries, where almost all Indonesian students were only able to possess the 3rd level of subject matter out of 6 , while students in developed countries were able up to level 4,5, or even 6 (Palungan, 2014).

It is not different from Indonesian achievement towards the review by Trends in International Mathematics and Science Study (TIMSS). It is reported that the mathematics and science skills of 7 th-grade students in 2007, Indonesia was ranked 35 th out of 49 countries. As for science, the average score of Indonesian students was 427 while Thailand and Malaysia were 471 and Singapore was ranked first with the score of 567 (Balitbang, 2015).

From PISA and TIMSS confirmed that Indonesian students' science ability was far below the average number compare to students in other countries across the world. Therefore, serious efforts and commitment are required to enhance the educational process, hope for better generations, and able to compete in PISA and TIMSS with other countries in the future.

Teachers and learning environment needs to put a better concerned towards students' higher-order thinking skills, especially for Biology course. Biology is the scientific knowledge that requires higher-order thinking skills. Thus because it is connected to the various systems of living things and its complex phenomena. Learning science means that students are directed to compare the predictions of the theory through the scientific method experiments. Hence, the scientific inquiry attitude should be compulsory towards science learning environment. Thus, triggers the way of thinking and the ability of scientific works as it is the necessary part of life skills matters

The Curriculum of 2013 emphasized on higherorder thinking skills (Ministry of Indonesian Education, 2015). Guided inquiry and free inquiry are the appropriate and precise learning techniques to enhance students' higher-order thinking skills. It gives students the access to fully explore their knowledge actively and independently. 
Research of inquiry in general conducted by Hendryarto and Amaria stated that inquiry learning model positively influenced students' higher-order thinking skills (Hendryarto, 2013); that guided inquiry learning model was better in improving students' learning outcomes and its higher-order thinking skills (King, Goodson, \& Rohani, 2017); (Yalamanchili, Vaddi, \& Anne, 2014)

there is a significant influence of chemical learning method which implemented by modified free inquiry learning towards students' achievement and their higher-order thinking skills (Pratiwi, 2012).

Contrast to the guided inquiry, free inquiry model as the highest types of inquiry based learning takes to another whole level. Students can design their problems, tools/materials, procedures, conclusion, and implication of certain problems means students are almost the same as doing the actual science itself (Friesen \& Scott, 2013). Darma, Sadia \& Suma (2014) then argues that these will lead to various themes and ideas of experiments, opportunity to act like a real scientist where it will be least or no guidance at all, and produce a different kind of problem-solving alternatives which depend on how the students construct their answer.

It is also confirmed by the research of Wilson, Taylor \& Kowalski (2010) that students in the inquiry-based group reached significantly higher levels of achievement than those who experiencing commonplace instruction. The effect was consistent across a range of learning goals (knowledge, reasoning, and argumentation). Another study performed by Damayanti, Ngazizah \& Setyadi (2013) indicates that critical thinking, part of higherorder thinking skills was in good category level. This means that guided inquiry learning can optimize students' critical thinking (Zaini, 2016).

There have been no research findings that assess the effectiveness of inquiry learning model related to the differences of students' ability as well as gender. Hence, the study will focus on improving students' higher-order thinking skills by comparing two types of inquiry learning models namely guided inquiry and free inquiry.

\section{METHODS}

The research was conducted by Quasi- Experiment method (Cohen, Manion, \& Morrison, 2011). The simple random sampling was used to determined specific treatments for each class (Emzir, 2013). Guided inquiry learning model for first experimental class and free inquiry learning model for the second experimental class. The Research design was nonequivalent pretest-posttest control group design For six weeks both classes use guided and free inquiry learning. For more details, the design was stated in the following table 1.

Table 1. Research Design

\begin{tabular}{llll}
\hline Class & Pretest & Treatment & Post test \\
\hline $\begin{array}{l}\text { Experiment } \\
\text { I }\end{array}$ & $\mathrm{O}_{1}$ & $\mathrm{X}_{\mathrm{M}}$ & $\mathrm{O}_{2}$ \\
$\begin{array}{l}\text { Experiment } \\
\text { II }\end{array}$ & $\mathrm{O}_{3}$ & $\mathrm{X}_{\mathrm{m}}$ & $\mathrm{O}_{4}$ \\
\hline
\end{tabular}

$\mathrm{O}_{1}$ and $\mathrm{O}_{3}$ are the symbols of students' higherorder thinking skills before treatment was given. $\mathrm{X}_{\mathrm{M}}$ is the guided inquiry learning experimental class while the free inquiry experimental class named as $\mathrm{X}_{\mathrm{m}}$. Post-treatment of guided inquiry learning symbolized with $\mathrm{O}_{2}$ as for free inquiry named $\mathrm{O}_{4}$.

\section{$2.1 \quad$ Instruments}

The test was designed based on the learning indicators of Fungi. There was nine essay test, in accordance to Revised Bloom's Taxonomy cognitive domain. The test description for measuring higherorder thinking skills was validated constructively by two experts. Additionally, empirical testing results show that the reliability value of 0,82 obtained. This means that the tested instruments have a high category of reliability.

\subsection{Data Analysis}

The statistical test of ANOVA SPSS version 22 (2017) was used to analyze the data of Normal Gain value (Meltzer, 2002).The data were gathered to find out the effectiveness of students' higher-order thinking skills and discover the relations of gender and students' ability category towards higher-order thinking skills.

\section{RESULTS AND DISCUSSION}

$\mathrm{N}-$ Gain from both experiments classes were tested by the Kolmogorov Smirnov to seek for its normality, and normal data were obtained for both classes (guided inquiry classes $(0,1>\mathrm{p} 0,05)$, while free inquiry class $(0,09>0,05)$. The homogeneity was then followed by the Homogeneity Levine test and show both classes were homogeneous. The ANOVA test results are shown in the following table 2 
Table 2. ANOVA N-Gain Improvement of HOTS of Guided Inquiry and Free Inquiry Class

\begin{tabular}{llllll}
\hline & $\begin{array}{l}\text { Sum of } \\
\text { Squares }\end{array}$ & df & $\begin{array}{l}\text { Mean } \\
\text { Square }\end{array}$ & F & Sig. \\
\hline $\begin{array}{l}\text { Between } \\
\text { Groups }\end{array}$ &, 000 & 1 &, 000 &, 00 &, 932 \\
$\begin{array}{l}\text { Within } \\
\text { Groups }\end{array}$ & 2,129 & 62 &, 034 & & \\
Total & 2,130 & 63 & & & \\
\hline
\end{tabular}

According to Table 2, the two models of inquiry do not give a significant difference of students' HOTS. ANOVA was further tested to discover the differences in the effectiveness of 2 types of inquiry learning models towards students' ability category. The test results as in the following table.

Table 3. ANOVA N-Gain Results towards HOTS of Students' Ability Category

\begin{tabular}{llllll}
\hline & $\begin{array}{l}\text { Sum of } \\
\text { Squares }\end{array}$ & df & $\begin{array}{l}\text { Mean } \\
\text { Square }\end{array}$ & F & Sig. \\
\hline $\begin{array}{l}\text { Between } \\
\text { Groups }\end{array}$ &, 863 & 2 &, 431 & 66,633 &, 000 \\
$\begin{array}{l}\text { Within } \\
\text { Groups }\end{array}$ &, 395 & 61 &, 006 & & \\
Total & 1,258 & 63 & & & \\
\hline
\end{tabular}

Table 3 reveals that there are differences of students' ability category (high, medium, low) in the two experimental classes. The Tukey test results are presented as the following table.

Table 4. Multiple Comparison Tukey HSD

\begin{tabular}{|c|c|c|c|c|c|c|}
\hline \multirow{6}{*}{ 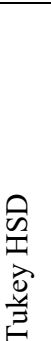 } & \multirow[t]{2}{*}{ low } & Medium & $-, 22072^{*}, 02719$ & ,000 &,- 2860 &,- 1554 \\
\hline & & High & $-, 40309^{*}, 03516$ & ,000 &,- 4875 &,- 3186 \\
\hline & medi & Low & ,22072* & ,000 & ,1554 & ,2860 \\
\hline & um & High & $-, 18237^{*}, 02825$ &, 000 &,- 2502 &,- 1145 \\
\hline & high & Low & ,40309 & ,000 & ,3186 &, 4875 \\
\hline & & Medium & ,18237*, 02825 &, 000 &, 1145 & ,2502 \\
\hline
\end{tabular}

Table 4 shows that there are significant differences in three types of students' ability categories. The results are in accordance with the previous review by Lott (1983) which reported that inquiry significantly gave a higher performance of higher-order thinking skills and learning outcomes.

Table 5. ANOVA N-Gain Results towards HOTS of Students' Gender

\begin{tabular}{llllll}
\hline & $\begin{array}{l}\text { Sum of } \\
\text { Squares }\end{array}$ & df & $\begin{array}{l}\text { Mean } \\
\text { Square }\end{array}$ & F & Sig. \\
\hline $\begin{array}{l}\text { Between } \\
\text { Groups }\end{array}$ &, 000 & 1 &, 000 &, 006 &, 941 \\
$\begin{array}{l}\text { Within } \\
\text { Groups }\end{array}$ & 2,129 & 62 &, 034 & & \\
Total & 2,130 & 63 & & & \\
\hline
\end{tabular}

Table 5 represents that there is no significant difference of students' higher-order thinking skills enhancement towards their gender. Both male and female of two experimental classes have the same opportunity to increase their higher-order thinking skills. It is also confirmed by the previous study of Heong, Othman, Yunos, Kiong, Hassan \& Mohamad (2011) which stated there is no significant difference of gender, achievement, and economic status towards higher-order thinking skills.

Essentially, the inquiry is a process which starts from formulating problems, making hypotheses, gathering evidence, verifying hypotheses, drawing temporary conclusions, and testing the conclusions (Zulfiani, 2007) with high mental processes. Staver and Bay (1987) argue that both guided and free inquiry use the same steps of practices. The different is on the amount of teacher's guidance in providing the information to the students. Guided inquiry allows teachers' guidance or contribution to the student's experiment performance, while free inquiry allows students to be able to explore their experiment issues in the laboratory and solve the problems which involving the scientific inquiry and science process skills.

\section{CONCLUSIONS}

Guided and free inquiry learning models positively significant towards students' ability category meanwhile no significant results of students' HOTS and gender from both experimental classes. Hence, it is concluded that guided and free inquiry learning models are suitable and recommended to enhance students' HOTS. 


\section{ACKNOWLEDGEMENTS}

The authors wish to thank Faculty of Education Sciences UIN Syarif Hidayatullah Jakarta.

\section{REFERENCES}

Balitbang, Ministry of Indonesian Education. (2015). Survei International TIMSS (Trends In International Mathematics and Science Study) Retrieved from http://litbang.kemdikbud.go.id/detail.php?id=214.html.

Cohen, L., Manion, L., Morrison, K. (2011). Research Metods in Education (7th ed.). New York : Routledge.

Damayanti, D. S., Ngazizah, N., K, Setyadi, E. K. (2013). Pengembangan LKS dengan Pendekatan Inkuiri Terbimbing untuk Mengoptimalkan Kemampuan Berpikir Kritis Peserta Didik pada Materi Listrik Dinamis SMA Negeri 3 Purworejo Kelas X Tahun Pelajaran 2012/2013. Radiasi, 3(1), pp. 58-62. http://ejournal.umpwr.ac.id/index.php/radiasi/article/vi ew/658.

Darma, I. W., Sadia, I. W., Suma., I. W. (2014). Studi Komparatif Model Pembelajaran Inkuiri Bebas dan Generatif terhadap Pemahaman Konsep dan Kreativitas Siswa. Jurnal Pendidikan IPA Indonesia, 4(1).

Emzir. (2013). Metodologi Penelitian Pendidikan: Kuantitatif dan Kualitatif. Jakarta: PT Raja Grafindo, Cet. VII.

Hendryarto, J \& Amaria. (2013). Penerapan Model Pembelajaran Inkuiri untuk Melatih Kemampuan Berpikir Tingkat Tinggi Siswa pada Materi Pokok Laju Reaksi. Unesa Journal of Chemical Education, 2(2), 151-158.

Friesen, S., Scott, D. (2013). Inquiry-Based Learning: A Review of the Research Literature. Alberta Ministry of Education.

Ministry of Indonesian Education. (2015). Perubahan Pola Pikir dalam Kurikulum 2013 Retrived: http://kemdikbud.go.id.html

King, F J., Goodson, L. Rohani, F. (2017). Higher Order Thinking Skills. Publication of the Educational Services Program, now known as the Center for Advancement of Learning and Assessment [www.cala.fsu.edu].

Heong, Y. M., Othman W B., Yunos J. B. M., Kiong, T.T., Hassan, R. B., Mohamad, M.M. B. (2011). The Level of Marzano Higher Order Thinking Skills among Technical Education Students. International Journal of Social Science and Humanity, 1(2), 121-125.

Lott, G. W. (1983) The Effect of Inquiry Teaching and Advance Organizers upon Student Outcomes in Science Education. Journal of Research in Science Teaching, 20(5), 437-451.

Meltzer, D. E. (2002). The Relationship between Mathematics Preparation and Conceptual Learning Gains in Physics: A Possible Hidden Variable in Diagnostic Pretest Scores. American Association of Physics Teachers, 70(12), 1259-1268.
Pratiwi, R. D. (2014) Penerapan Constructive Controversy dan Modified Free Inquiry terhadap Keterampilan Berpikir Tingkat Tinggi Mahasiswa Pendidikan Biologi. Jurnal Formatif, 4(2), 100-111.

Staver, J. R., Bay, M. (1987). Analysis of the Project Synthesis Goal Cluster Orientation and Inquiry Emphasis of Elementary Science Textbook. Journal of Research in Science Teaching, 24(7), 629-643, DOI: 10.1002/tea.3660240704.

Wilson, C. D., Taylor, A. J., Kowalski, S. M. (2010). The Relative Effects and Equity of Inquiry-Based and Commonplace Science Teaching on Students' Knowledge, Reasoning, and Argumentation. Journal of Research and Science Teaching, 47(3), 276-301. DOI: $10.1002 /$ tea.20329.

Yalamanchili, B. S., Vaddi, R.S., Anne, K. R. (2014). Inquiry-Based Guided Learning to Enhance Interest and Higher-Order Thinking in Engineering Graduates: A Computing Education Perspective. Proceedings of the International Conference on Transformations in Engineering Education, 297-305.

Zaini, M. (2016). Guided Inquiry Based Learning on the Concept of Ecosystem Toward Learning Outcomes and Critical Thinking Skills of High School Students. IOSR Journal of Research \& Method in Education, 6( 6), 50-55

Zulfiani, (2007). Inkuiri dalam Pendidikan IPA. Jakarta: PIC UIN Jakarta. Retrieved from : http://repository.uinjkt.ac.id/dspace/handle/123456789/ 35835 . 